PSYCHOLOGY

\title{
ПСИХОЛОГІЧНІ ОСОБЛИВОСТІ ОСІБ, СХИЛЬНИХ ДО УНИКАННЯ В СКЛАДНИХ ЖИТТЕВИХ СИТУАЦІЯХ
}

\author{
Анна Вовк, доцент кафедри психології, кандидат психологічних наук, \\ Україна, Львів, Львівський національний університет
}

DOI: https://doi.org/10.31435/rsglobal_ws/31032020/6979

\section{ARTICLE INFO}

Received: 20 January 2020

Accepted: 11 March 2020

Published: 31 March 2020

\section{KEYWORDS}

avoidance, temperament, character, communicative, perceptive and interactive competence, emotional intelligence and barriers in communication, self-regulation, cognitive and activity style, life values, coping strategies, conflict behavior, stress-resilience, emotional state and direction. \begin{abstract}
A comparison and analysis of temperament peculiarities and character features, self-regulation, cognitive and activity style, communicative, perceptive and interactive competence, emotional intelligence and barriers in communication, emotional states and direction, life values, coping strategies for persons with different level of inclination to avoidance in complex life situations are made. Interconnections between inclination to avoidance and rigidity, reactivity, assertiveness, social contacting in complex life situations, asocial inclination, moral normativity, activity modeling and evaluation, chaotic and controlled cognitive and activity style, self-regulation, communicative competence, social intuition, conflict behavior, stress-resilience, aggressiveness, sadness, gnostic and gloristic emotional direction are analyzed and interpreted.
\end{abstract}

Citation: Анна Вовк. (2020) Psykholohichni Osoblyvosti Osib, Skhylnykh do Unykannia v Skladnykh Zhyttievykh Sytuatsiiakh. World Science. 3(55), Vol.4. doi: 10.31435/rsglobal_ws/31032020/6979

Copyright: (C) 2020 Анна Вовк. This is an open-access article distributed under the terms of the Creative Commons Attribution License (CC BY). The use, distribution or reproduction in other forums is permitted, provided the original author(s) or licensor are credited and that the original publication in this journal is cited, in accordance with accepted academic practice. No use, distribution or reproduction is permitted which does not comply with these terms.

Вступ. Уникання як копінг-стратегія в складних життєвих ситуаціях є мало дослідженим психологічним феноменом 3 комплексною і невизначеною детермінацією, що робить його перспективною лінією для наукових досліджень. Складною життєву ситуацію робить дискомфорт, який переживає людина при усвідомленні недостатності власних (або теоретично доступних) зовнішніх і внутрішніх ресурсів для ефективного реагування на виклики середовища. Гострота переживання інтенсивності власних потреб, недостатність ресурсів, що переживається як критична та невирішувана, дефіцит часу для вирішення проблеми, ситуація конкурентної боротьби 3 соціальним оточенням, внутрішні конфлікти та сумніви щодо оцінки важливості та цінності вирішення проблеми, необхідність вибору способу вирішення, виникнення обмежень та перешкод у реалізації планів виходу 3 ситуації - все це викликає наростання дискомфорту, стресове напруження, що сприяє когнітивній та поведінковій активізації, мобілізації адаптаційних можливостей та актуалізації особистісного потенціалу, але здебільшого у випадку достатньої психологічної стійкості особистості та опірності стресу.

Більшість класифікацій копінг-стратегій використовують їх дихотомічний розподіл на «роботу з проблемою» та «роботу із ставленням до проблеми», тобто розрізняють активні і сфокусовані на проблемі зусилля та внутрішні спроби переформулювати, трансформувати, здійснити когнітивну переоцінку проблеми для зниження стресового напруження [1]. E.K. Koplik [2] зосереджує увагу на когнітивних копінг-стратегіях та виокремлює стратегію пошуку інформації та стратегію закритості для інформації (що власне і відповідає стратегії 
уникання). P.P. Vitaliano [3] розглядає уникання серед емоційно-орієнтованих копінгів, до ряду яких також включає самозвинувачення та переважне трактування (витлумачення). Д.В.Бикова [4] проводила дослідження копінг-стратегії уникання (на прикладі шопінгу і прокрастинації), результати якого відносять уникання до груп емоційно-орієнтованого (прокрастинація) та соціально-орієнтованого (шопінг) стилів.

Деякі дослідники надають перевагу тому, щоб поділяти копінг-стратегії на функціональні та дисфункціональні (непродуктивні), при чому уникання використовується як синонім дисфункціональних копінг-стратегій, які пов'язані із нездатністю дати собі раду із ситуацією [5]. Інший важливий критерій для поділу копінг-стратегій це фактор включеностіневключеності (уникання) (Hofmann S.G., Нау А.C.) [6]. Включеність передбачає тестування різноманітних способів впливу на ситуацію та пов'язані 3 нею емоції, в той час як невключеність передбачає втечу від ситуації та пов'язаних з нею емоцій (C.Carver, J.ConnorSmith, 2010) [7]. Невключеність в першу чергу може бути розглянута як емоційно-фокусована копінг-стратегія, оскільки вона передбачає докладання зусиль у напрямку уникнення неприємних переживань за допомогою втечі, відмови та дистанціювання. Стратегія невключеності часто розглядається як дезадаптивна, хоча в ранньому гострому періоді переживання травматичного епізоду, наприклад, вона може бути хорошим варіантом, проте, не залишається таким варіантом у довготривалій перспективі. Також, дистанціювання або спроба вийти з ситуації, мінімізувати міру включеності в неї шляхом мінімізації ії важливості може бути адаптивною емоційно-фокусованою копінг-стратегією. Дистанціювання тоді $є$ подібним до техніки дифузії з біхевіоральної «Терапії Прийняття та Зобов'язань» (АCT; S.C.Hayes, K.D.Strosahl, K.G.Wilson, 2012) [8]. Дистанціювання від негативної думки допомагає зменшити віру в неї, заспокоїтись, відновити сили i, наприклад, на другому етапі перейти до копінгстратегій включеності, таких як асертивна поведінка, пошук соціальної підтримки, прийняття, емоційна регуляція, когнітивна реструктуризація. Втеча $\epsilon$ проблемно-фокусованою стратегією невключеності та уникання. Поведінка втечі виникає як відповідь на загрозу і дозволяє уникнути іï, виключити цю загрозу з своєї життєвої ситуації повністю або частково. Гнучке та точне застосування такого підходу дозволяє зробити його ефективною копінг-стратегією, проте, надмірне покладання на втечу, наприклад, соціальне уникання при переоцінці міри загрозливості ситуації (страх критики, сорому, публічного виступу, перебування в центрі уваги) $\epsilon$ дезадаптивним, оскільки призводить до соціальної ізоляції та зростання тривоги і депресії (уникання породжує ще більше уникання). Деякі стратегії невключеності можуть самі по собі створювати проблемні ситуації, наприклад, вживання психоактивних речовин, що призводить до проблем із здоров'ям та створює загрозу для соціального статусу та функціонування [6].

Також уникання можна поділити на пасивну і активну форму [6]. Активне уникання це поведінка, покликана запобігти нанесенню шкоди (втеча), яка є фактично формою контролю над середовищем, яка дозволяє знизити рівень тривоги. Подібно до того, людина, яка пережила травму посилено намагається контролювати середовище, з часом включаючи в цей контроль (i список речей, яких слід уникати), все більше елементів, що притамовує переживання тривоги, $\mathrm{i}$ тоді відносно рівня тривоги ця копінг-стратегія виявляється ефективною. Це може бути однією 3 причин, 3 яких поведінкова активація (прості активності, що приносять задоволення) $\epsilon$ ефективною інтервенцією в терапії депресивних станів. Можливо, складна діяльність, яка потребує часу і призводить до помилок, не змогла б тут допомогти і навіть спровокувала б поглиблення депресивного стану, оскільки $б$ не давала ефекту швидкого та ефективного опанування. Якщо загрозлива ситуація є настільки інтенсивною, що спричиняє до переживання безпорадності, поведінкова відповідь у вигляді уникання обов'язково виникне як тимчасове явище, перш ніж утворяться можливості для застосування інших копінг-стратегій [6].

Здебільшого поняття копінгу розглядається в контексті відповіді на загрозу чи життєву складність, проте, деякі копінг-стратегії можуть передувати виникненню чи зростанню загрози, зокрема, проактивне (випереджуюче) уникання («безпечна поведінка»), яка також дозволяє мінімізувати переживання тривоги (L.G. Aspinwall, S.E. Taylor, 1997) [9]. Проактивне уникання $\epsilon$ завжди проблемно-фокусованим і включає дослідження потенційної загрози, задіяння ресурсів, що дозволяють краще захистити себе від неї, включаючи розвиток толерантності та стресостійкості. Також форми безпечної поведінки можна поділити на превентивні та відновлюючі. Наприклад, якщо присутній страх зараження, якому відповідає у поведінці надмірна частота миття рук, то 
превентивною стратегією бути активне уникання потенційно заражених об'єктів, а відновлюючою - санітарна обробка рук. Періоди спокою $є$ свого роду позитивним підкріпленням «безпечної поведінки» [6]. M. McKay, P. Fanning, P. Zurita [10] поділяють уникання на такі підвиди, як ситуаційне (зовнішнє, уникнення ситуацій), когнітивне (внутрішнє, уникнення думок), захисне (компульсивна поведінка, перфекціонізм, прокрастинація), соматичне та субституційне (іжа, психоактивні речовини, шопінг, гемблінг тощо).

Психологічні дослідження схильності до уникаючої копінг-стратегії (уникання стресових думок або ситуацій на поведінковому та когнітивному рівні) показали, що така схильність пов'язана $з$ вищими показниками депресії (M.A. Herman-Stahl, 1995 [11]; I. Seiffge-Krenke, 1998) [12], тривоги (H. Lewis, W. Kliewer, 1996) [13], складностями адаптації до шкільного навчання та колективу (D.L. Causey, E.E. Dubow, 1993) [14]. R.G. Servatius [15] протиставляє надвираженість реакції уникання у вигляді тривожних розладів та ПТСР, які представлені симптомами самообмеження інтеракцій з соціальним оточенням та середовищем взагалі, та недовираженість реакції уникання у вигляді депресії та суіцидальних нахилів та спроб, що представлені порушенням особистісних кордонів катастрофічною недооцінкою власних ресурсів та загальною деморалізацією. Інші дослідження показали, що школярі, схильні до уникання навпаки мають менше проблем з дисципліною (W. Kliewer, 1991; N. Eisenberg et al., 1993) [16] та вищі показники соціальної компетентності (W. Kliewer, I.N. Sandler, 1993) [17]. Дослідники припускають, що уникаючий копінг $є$ більш ефективним тоді, коли ситуація $є$ неконтрольованою [11] (i тоді уникання сприяє тому, щоб іï масштаб принаймні не збільшувався), або занадто лякаючою (S. Roth, L.G. Cohen, 1986) [18] або нетривалою (оскільки при зростанні тривалості ситуація однозначно потребуватиме вирішення) [19].

Метою дослідження $є$ виявлення психодинамічних особливостей, характерологічних рис, особливостей організації когнітивної діяльності та поведінки, вольової саморегуляції, копінгстратегій, комунікативної, перцептивної та інтерактивної компетентності, емоційного інтелекту та бар'єрів у спілкуванні, стресостійкості, поведінки в конфлікті, життєвих цінностей, емоційних станів та емоційної спрямованості осіб, схильних до уникання в складних життєвих ситуаціях.

Методи дослідження. В дослідженні були використані опитувальник психодинамічних рис особистості (Б.Н. Смірнов), опитувальник 16 РF Р.Б. Кеттелла, методика дослідження емоційної спрямованості особистості (Б. Додонов), 4-модальний опитувальник (Л. Рабинович); тест «Самооцінка психічних станів» (Г. Айзенк), опитувальник «Способи копінгу» (А.Лазарус, С.Фолькман), методика діагностики стратегій та моделей поведінки подолання С.Хобфолла, опитувальник «Стиль саморегуляції поведінки» В.І. Моросанової, методика аналітичного огляду стилю навчання Л. Ребекки (для визначення когнітивно-діяльнісного стилю особистості), тест С.Бубнової для визначення реальної структури ціннісних орієнтацій особистості, тестопитувальник «Дослідження вольової саморегуляції» (А.В. Звєрьков, Е.В. Ейдман), тест комунікативної та соціальної компетентності (В.В.Бойко), тест на визначення схильності до співзалежності (Б. та Дж. Уайнхолд), методика самооцінки психічної стійкості в міжособистісних стосунках (М.В. Секач, В.Ф.Перевалов, Л.Г. Лаптєв), опитувальник «Емоційні бар’єри у спілкуванні" (В.В. Бойко), методика діагностики перцептивно-інтерактивної компетентності (Н.П. Фетіскін), тест емоційного інтелекту (Н. Холл), методика експрес-діагностики поведінкового стилю в конфліктній ситуації, тест самооцінки стресостійкості (С. Коухен, Г. Вілліансон). Для статистичної обробки результатів дослідження використовувались методи кластерного (метод kсередніх), порівняльного (t-критерій Стьюдента) та кореляційного аналізу.

Результати дослідження. В дослідженні взяли участь 128 осіб, з яких 82 особи виявили меншу схильність до уникання в складних життєвих ситуаціях (64,06\%) і 46 осіб - більшу схильність до уникання в складних життевих ситуаціях $(35,94 \%)$. Розподіл на підгрупи був здійснений за допомогою процедури кластерного аналізу (метод k-середніх).

Уникання прямо пов'язане 3 ригідністю нервових процесів $(\mathrm{r}=0,18, \mathrm{p} \leq 0,05)$ та збудливістю нервової системи $(\mathrm{r}=0,35, \mathrm{p} \leq 0,05)$, що обумовлює високу реактивність осіб, схильних до уникання у відповідь на впливи середовища та значну тривалість нервових та психічних процесів без повторного впливу, що робить інтенсивну стимуляцію фактором значного стресу для них. Уникання дозволяє зменшити інтенсивність стимуляції, але у досить радикальний та аварійний спосіб, коли виходу з ситуації не передує оцінка важливості, значимості стимулів та їх диференціація. В такому випадку важливі зовнішні і внутрішні 
фактори можуть бути недооцінені або і взагалі проігноровані, що зменшує реалістичність бачення ситуації та імовірність задоволення потреб особистості.

Особи, що схильні до уникання в складних життєвих ситуаціях, також більш схильні до переживання злості і гніву (М1емп=16,58, М2емп $=20,9, \mathrm{t}=-2,92, \mathrm{p} \leq 0,01)$, більш схильні до проявів агресії (М1емп=7,37, М2емп=9,52, $\mathrm{t}=-2,33, \mathrm{p} \leq 0,05)$, більш схильні до переживання суму (M1емп $=11,53, \mathrm{M} 2 \mathrm{eмп}=15,55, \mathrm{t}=-2,35, \mathrm{p} \leq 0,05)$. Особи, що схильні до уникання в складних життєвих ситуаціях, менш здатні керувати власними емоціями (М1емп $=3,05$, М2емп=1,55, $\mathrm{t}=4,52, \mathrm{p} \leq 0,01)$, менш здатні до самоконтролю (М1емп=12,02, М2емп $=10,91, \mathrm{t}=2,48, \mathrm{p} \leq 0,05$ ), таким особам більш властиве домінування негативних емоцій (М1 емп $=1,16$, М2емп $=2,05, \mathrm{t}=-$ $3,23, \mathrm{p} \leq 0,01)$, нижчі показники емоційної зрілості (М1емп=11,42, М2емп $=10,34, \mathrm{t}=2,06, \mathrm{p} \leq 0,05)$. Уникання прямо пов'язане із схильністю до переживання злості та гніву $(\mathrm{r}=0,33, \mathrm{p} \leq 0,05)$, схильністю до переживання суму $(\mathrm{r}=0,45, \mathrm{p} \leq 0,05)$, домінуванням негативних емоцій $(\mathrm{r}=0,29$, $\mathrm{p} \leq 0,05)$, схильністю до проявів агресії $(\mathrm{r}=0,29, \mathrm{p} \leq 0,05)$ та перебуває в оберненому зв'язку з емоційною стабільністю ( $\mathrm{r}=-0,33, \mathrm{p} \leq 0,05)$, емоційною зрілістю ( $\mathrm{r}=-0,18, \mathrm{p} \leq 0,05)$, вмінням керувати власними емоціями ( $\mathrm{r}=-0,37, \mathrm{p} \leq 0,05)$, адекватністю прояву емоцій $(\mathrm{r}=-0,38, \mathrm{p} \leq 0,05)$, емоційною обізнаністю, тобто здатністю до правильної інтерпретації емоційних переживань інших людей $(\mathrm{r}=-0,32, \mathrm{p} \leq 0,05)$, стресостійкістю $(\mathrm{r}=-0,27, \mathrm{p} \leq 0,05)$. Брак можливостей активного впливу на ситуацію та оточуюче середовище, брак здатності до мобілізації власних зусиль для вирішення проблем, пасивна позиція поглиблює фрустрацію особи, що переживає складну життєву ситуацію. Ї̈і потреби залишаються незадоволеними, міра незадоволеності собою та життям зростає, ресурси пристосування поступово вичерпуються, що призводить до зростання емоційного напруження та поглиблення депресивних переживань особистості, переживання недостатності контролю над власними переживаннями, емоційним станом та життям взагалі. Відсутність адекватного та реалістичного зворотного зв'язку від соціального оточення зменшує імовірність задоволення соціальних потреб особистості та поглиблює іiі переживання нерозуміння та самотності.

Уникання перебуває в оберненому зв'язку із здатністю до вольової саморегуляції ( $\mathrm{r}=-$ $0,31, \mathrm{p} \leq 0,05)$, наполегливістю $(\mathrm{r}=-0,33, \mathrm{p} \leq 0,05)$, самоволодінням $(\mathrm{r}=-0,28, \mathrm{p} \leq 0,05)$, отже, здатність до самоорганізації та самомоніторингу, мобілізації власних зусиль, калібрування їх інтенсивності та вибору напрямку застосування може бути суттєво обмежена та значною мірою заблокована через недостатню обізнаність щодо зовнішніх і внутрішніх умов та ресурсів, спричинені схильністю до уникання. Слабкість вольових механізмів може виникати також через недооцінку власних сил і можливостей, невпевненість в собі, повторювані переживання власної неефективності, непродуктивності власних зусиль.

Особи, що схильні до уникання в складних життєвих ситуаціях, $\epsilon$ менш комунікабельними (М1емп $=13,64, \mathrm{M} 2 \mathrm{e} \Pi=11,82, \mathrm{t}=3,3, \mathrm{p} \leq 0,01$ ), мають нижчі показники соціальної сміливості (М1емп=7,6, М2емп $=6,5, \mathrm{t}=-2,09, \mathrm{p} \leq 0,05)$, отже, їх стратегія уникання стосується також ситуацій спілкування. Уникання прямо пов'язане з підозріливістю ( $\mathrm{r}=0,17$, $\mathrm{p} \leq 0,05)$, прагненням до уникнення критики $(\mathrm{r}=0,23, \mathrm{p} \leq 0,05)$, схильністю до поступок $(\mathrm{r}=0,19$, $\mathrm{p} \leq 0,05)$ та втечі в конфліктних ситуаціях $(\mathrm{r}=0,22, \mathrm{p} \leq 0,05)$. Особи, схильні до уникання в складних життєвих ситуаціях через наявність внутрішніх обмежень та страхів (оцінки, соціальної взаємодії, критики) можуть зводити свої соціальні контакти до невеликої кількості безпечних та необхідних для власного емоційного комфорту, а також суттєво обмежувати свої потреби та інтереси в конфліктних ситуаціях для уникнення конфронтації з соціальним оточенням (проте, потім почуваються незадоволеними, непідтриманими, напруженими i фрустрованими). Особи, що схильні до уникання в складних життєвих ситуаціях, мають нижчі показники комунікативної та соціальної компетентності (М1емп=77,33, М2емп $=72,35, \mathrm{t}=3,19$, $\mathrm{p} \leq 0,01$ ), нижчі показники соціальної інтуїції (М1емп $=2,65, \mathrm{M} 2 \mathrm{e} п=0,44, \mathrm{t}=2,64, \mathrm{p} \leq 0,01$ ). Уникання перебуває в оберненому зв'язку 3 комунікабельністю $(\mathrm{r}=-0,22, \mathrm{p} \leq 0,05)$, комунікативно-соціальною компетентністю $(\mathrm{r}=-0,23, \mathrm{p} \leq 0,05)$, толерантністю $(\mathrm{r}=-0,18, \mathrm{p} \leq 0,05)$, соціальною інтуіцією ( $\mathrm{r}=-0,17, \mathrm{p} \leq 0,05)$, установкою на взаємопізнання у спілкуванні $(\mathrm{r}=-0,19$, $\mathrm{p} \leq 0,05)$, тобто, ресурсність осіб, схильних до уникнення в спілкуванні та взаємодії з соціальним середовищем є достатньо низькою через обмеженість їх соціального досвіду, при тому, що їм також властиві вищі показники емоційної залежності від оточуючих (М1емп=40,16, М2емп $=48,18, \mathrm{t}=10,51, \mathrm{p} \leq 0,01)$. Уникання перебуває в оберненому зв'язку 3 соціальною 
автономністю ( $\mathrm{r}=-0,18, \mathrm{p} \leq 0,05)$ та психічною стійкістю у міжособистісних стосунках $(\mathrm{r}=-0,27$, $\mathrm{p} \leq 0,05)$. Через страх порушення власних границь вони можуть обмежувати власні соціальні контакти, при цьому відчуваючи брак довіри до власних почуттів, думок та внутрішніх критеріїв оцінки реальності. Проявляючи невпевненість у ситуаціях спілкування і взаємодії, вони отримують негативний зворотний зв'язок, почуваються непідтриманими, розчаровуються, переживають незадоволеність власних соціальних потреб, при цьому залишаючись у залежності від зовнішніх критеріїв оцінки.

Уникання перебуває в оберненому зв'язку із схильністю до асертивних дій в складних життєвих ситуаціях $(\mathrm{r}=-0,31, \mathrm{p} \leq 0,05)$, що свідчить про брак сміливості та впевненості в озвученні власних потреб та інтересів, вимог та очікувань та в конкуренції з іншими людьми за реалізацію інтересів. Якщо особа оцінює свої сили у боротьбі за щось бажане як недостатні, а своє право на задоволення потреб як другорядне у порівнянні з правами оточуючих, вона відступає, залишаючись незадоволеною, при чому іноді передчасно i навіть тоді, коли виявляється, що в гострій конфронтації не було потреби, інші претенденти теж готові були на поступки та компроміси і в неї була б велика імовірність отримати бажане, якщо б вона проявила більшу наполегливість та стійкість. Це саме той випадок, коли мотивація уникнення невдачі $є$ вищою за мотивацію отримання успіху, коли людина зберігає свій спокій, але і не отримує можливостей для розвитку.

Уникання прямо пов'язане із схильністю до вступу в соціальний контакт в складних життєвих ситуаціях $(\mathrm{r}=0,25, \mathrm{p} \leq 0,05)$, отже, при браку внутрішніх критеріїв оцінки складних ситуацій та невпевненості у власних силах і можливостях, недооцінка власних ресурсів збільшує імовірність пошуку соціально підтримки тоді, коли ситуація виходить 3-під контролю, стає критичною. Проте, така підтримка може прийти занадто пізно або бути невідповідною за формою та кількістю, якщо виникають складності із формуванням запиту про таку підтримку. Будь-яке нерозуміння 3 боку оточуючих може посилювати тривогу особи, схильної до уникання, розчаровувати іiї та зменшувати імовірність та адекватність іiї прохань про соціальну підтримку у майбутньому.

Особам, що схильні до уникання в складних життєвих ситуаціях, більш притаманна схильність до обережних дій в складних життєвих ситуаціях (М1емп $=21,05$, М2емп $=22,37, \mathrm{t}=-$ $2,04, \mathrm{p} \leq 0,05)$ та імпульсивних дій в складних життєвих ситуаціях (М1емп=18,07, М2емп=19,43, $\mathrm{t}=-2,94, \mathrm{p} \leq 0,01)$. Уникання прямо пов'язане із схильністю до імпульсивних дій в складних життєвих ситуаціях $(\mathrm{r}=0,23, \mathrm{p} \leq 0,05)$. Недооцінка власних ресурсів вирішення проблем, невпевненість у власних силах призводить до гальмування, відтермінування активності, спрямованої на таке вирішення. Хронічне відкладання вирішення проблеми загрожує тим, що в результаті вона потребуватиме негайного розв'язання, або внутрішнє напруження зросте настільки, що виникне необхідність у негайній його розрядці без пошуку оптимальної для цього форми та врахування всіх важливих обставин.

Особам, що схильні до уникання в складних життєвих ситуаціях, також більш притаманні непрямі дії в складних життєвих ситуаціях (М1 емп=19,22, М2емп=20,66, $\mathrm{t}=-2,58, \mathrm{p} \leq 0,05)$, уникання прямо пов'язане із схильністю до непрямих дій в складних життєвих ситуаціях $(\mathrm{r}=0,19, \mathrm{p} \leq 0,05)$, отже, особи, схильні до уникання через наявність різноманітних психологічних бар'єрів обирають не найшвидші та не найбільш ефективні способи вирішення життєвих проблем. Непрямий спосіб вирішення може виникати як наслідок недостатнього розуміння суті проблеми та недооцінки іiі значимості (тобто, уникання іiї осмислення) або уникнення конфронтації з нею та соціальним оточенням та активного пошуку додаткових ресурсів. Такий підхід може суттєво подовжувати та ускладнювати пошук та втілення ефективного рішення, що спричиняс до зайвих енерговитрат, додаткових стресових ситуацій та формування негативного образу Я (як такого, що володіє недостатньою кількістю ресурсів для вирішення життєвих проблем).

Особи, що схильні до уникання в складних життєвих ситуаціях, також більш схильні до асоціальних дій в складних життєвих ситуаціях (М1емп=15,92, М2емп=17,84, t=-2,49, p $\leq 0,05$ ), що показує їх упереджені і ворожі установки до соціального оточення, також вони мають нижчі показники моральної нормативності (М1емп $=7,78$, M2емп $=7,02, \mathrm{t}=1,99, \mathrm{p} \leq 0,05)$. Уникання прямо пов'язане 3 асоціальністю $(\mathrm{r}=0,25, \mathrm{p} \leq 0,05)$ та перебуває в оберненому зв'язку 3 моральною нормативністю $(\mathrm{r}=-0,31, \mathrm{p} \leq 0,05)$. Особи, схильні до уникання можуть приписувати свої знижені моральні критерії та асоціальні бажання іншим людям за механізмом проективної 
ідентифікації і уникати контактів з ними (оскільки небезпека породжує обережність, тривогу і страх). Вони можуть опинитися в ізоляції, і тоді міра їх налаштованості проти інших буде зростати, а негативні прогнози стосовно інших підтверджуватись.

Особи, що схильні до уникання в складних життєвих ситуаціях, також більш схильні до дистанціювання в складних життєвих ситуаціях (М1емп=7,31, М2емп=12,06, t=-2,96, p $\leq 0,01$ ). Уникання прямо пов'язане із схильністю до дистанціювання в складних життєвих ситуаціях $(\mathrm{r}=0,59, \mathrm{p} \leq 0,05)$. Дистанціювання - це стратегія, наближена до уникання, оскільки воно досягається за рахунок зниження суб'єктивної значимості проблеми та ступеню емоційного включення в неї, знецінення, переключення уваги, використання гумору та раціоналізації. Такий підхід знижує емоційне напруження, проте, не сприяє конструктивному вирішенню складної ситуації.

Особи, що схильні до уникання в складних життєвих ситуаціях, також більш схильні до прийняття відповідальності в складних життєвих ситуаціях (М1емп=9,63, М2емп=12,61, $\mathrm{t}=-3,53, \mathrm{p} \leq 0,01)$. Уникання прямо пов'язане із схильністю до прийняття відповідальності в складних життєвих ситуаціях $(\mathrm{r}=0,4, \mathrm{p} \leq 0,05)$. Визнання суб'єктом власної ролі у виникненні проблеми (при складності активної участі у іiі безпосередньому вирішенні) 3 вираженим компонентом самокритики та самозвинувачення може призвести до хронічної незадоволеності собою, недооцінки власних ресурсів та невпевненості щодо власних можливостей, що сприяє закріпленню стратегії уникання та відкладання вирішення проблеми.

Особам, що схильні до уникання в складних життєвих ситуаціях, менш притаманний контроль в когнітивно-діяльнісному стилі (М1емп $=15,45, \mathrm{M} 2 \mathrm{eмп}=13,61, \mathrm{t}=2,1, \mathrm{p} \leq 0,05)$, уникання перебуває в оберненому зв'язку з контролем як компонентом когнітивно-діяльнісного стилю (r=$0,19, \mathrm{p} \leq 0,05)$, тобто, особи, схильні до уникання менш схильні до структурування, планування та моніторингу своєї діяльності, що може ускладнювати досягнення проміжних та кінцевих ії цілей, ставити під загрозу терміни ії виконання, призводити до прокрастинації та стресових ситуацій. Уникання прямо пов'язане 3 хаосом як компонентом когнітивно-діяльнісного стилю ( $\mathrm{r}=0,16$, $\mathrm{p} \leq 0,05)$, отже, відкладання вирішення проблемних ситуацій, відсутність стратегії та планомірності у їх вирішенні призводить до накопичення та ускладнення таких ситуацій, що збільшує імовірність потреби у їх аварійному, стихійному вирішенні у майбутньому і ставить під питання ефективність та екологічність такого вирішення. Особи, що схильні до уникання в складних життєвих ситуаціях, мають вищі показники абстрактного інтелекту (М1емп=8,4, $\mathrm{M} 2 \mathrm{e} п=9,59, \mathrm{t}=-2,37, \mathrm{p} \leq 0,05)$, отже, мають виражений інтелектуальний потенціал, який, проте, можуть використовувати нераціонально, наприклад, вдаючись до побудови теоретичних конструкцій та планів, які ніколи не будуть втілені у життя, фантазування.

Особи, що схильні до уникання в складних життєвих ситуаціях, мають нижчі показники схильності до оцінки результатів діяльності як індивідуального стилю саморегуляції (M1 емп $=5,89, \mathrm{M} 2 \mathrm{eм} \Pi=5,26, \mathrm{t}=2,07, \mathrm{p} \leq 0,05)$. Уникання перебуває в оберненому зв'язку із схильністю до оцінки результатів діяльності як індивідуального стилю саморегуляції ( $\mathrm{r}=-0,34$, $\mathrm{p} \leq 0,05)$. Брак здатності до реалістичної оцінки своєї діяльності та поведінки, адекватної самооцінки, виважених суб'єктивних критеріїв може випливати з недовіри до себе і власних почуттів, недооцінки власних ресурсів та можливостей контролю над власними проявами i життям взагалі. Тоді місце внутрішніх критеріїв займають зовнішні, думка оточуючих людей стає важливішою за власну, втрачається особистісна автономність. Одним із способів відновити власні порушені границі тоді буде уникнення вирішення проблем та соціальних контактів.

Уникання перебуває в оберненому зв'язку із схильністю до моделювання як індивідуального стилю саморегуляції ( $\mathrm{r}=-0,27, \mathrm{p} \leq 0,05)$, що свідчить про знижений рівень розвитку та деталізованості у осіб, схильних до уникання уявлень про зовнішні і внутрішні значимі умови, усвідомленості та адекватності таких уявлень. Тоді реалістичні вибір цілей та побудова планів і стратегій іiі реалізації замінюється фантазуванням, вони часто не здатні вчасно зауважити зміни умов, що призводить до невдач у організації діяльності. Упередженість

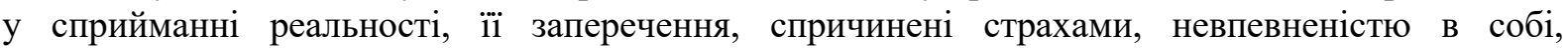
недооцінкою власних ресурсів в кінцевому рахунку призводять до неможливості повноцінної самореалізації та закріплення уявлення про власну неспроможність та безпорадність.

Уникання прямо пов'язане 3 життєвою цінністю відпочинку $(\mathrm{r}=0,15, \mathrm{p} \leq 0,05)$, що може відображати низький рівень ресурсності осіб, схильних до уникання в складних життєвих ситуаціях, високу міру виснаження, через які вони уникають контактів, або низьку мотивацію 
досягнення, коли вони суттєво обмежують свої потреби та амбіції, обираючи для себе спокій і розслаблення (а разом з тим іноді і хронічну фонову незадоволеність). Уникання перебуває в оберненому зв'язку з глоричною емоційною спрямованістю $(\mathrm{r}=-0,33, \mathrm{p} \leq 0,05)$, романтичною емоційною спрямованістю ( $\mathrm{r}=-0,47, \mathrm{p} \leq 0,05)$, гностичною емоційною спрямованістю ( $\mathrm{r}=-0,32$, $\mathrm{p} \leq 0,05$ ), що засвідчує обмеженість їх потреб у пізнанні та самоствердженні (іноді мабуть цілком свідоме самообмеження), визнанні оточуючими, підтвердженні власної цінності та значимості через низьку ресурсність, незадоволеність більш важливих потреб, переживання браку підтримки та розуміння з боку оточуючих, невпевненість в собі, які спричиняють до вибору на користь обмеження самопред’явлення та самореалізації, свого роду економ-режим, що дозволяє зберігати стабільність (в точу числі стабільність уявлення про власне Я як недостатньо ефективне та ресурсне).

Висновки. 1. Уникання належить до пасивних, непрямих, емоційно-фокусованих копінгстратегій невключеності і розглядається великою кількістю дослідників серед дисфункціональних (непродуктивних) способів опанування ситуацією. В свою чергу уникання поділяється на такі підвиди як втеча (проблемно-фокусована копінг-стратегія), відмова та дистанціювання (емоційнофокусовані копінг-стратегіï), пасивне, активне та проактивне (випереджуюче) уникання, при чому в деяких випадках уникання є єдино можливим, тимчасово найкращим (перед переходом до інших копінг-стратегій) та превентивним щодо виникнення або ускладнення проблемних ситуацій способом опанування, який призводить до зниження рівня тривоги і депресії та відновлення почуття контролю над собою, середовищем та власним життям взагалі. Проте, коли уявлення про загрозу перебільшене, а ресурси недооцінюються, уникання може спричиняти до соціальної ізоляції та зростання рівнів тривоги і депресії.

2. Вибір копінг-стратегії уникнення пов'язаний з психодинамічними рисами особистості, зниженим загальним емоційним фоном та емоційним інтелектом, зниженою здатністю до вольового контролю та саморегуляції, попереднім негативним соціальним досвідом, негативними соціальними установками, наявністю емоційних бар'єрів у спілкуванні та низьким рівнем розвитку соціальних, інтерактивних та комунікативних навичок і вмінь, а також з вибором неоптимальних та непродуктивних стратегій досягнення цілей в когнітивній активності, поведінці подолання та діяльності, зниженням активності та рівня домагань загалом.

3. Зважаючи на велику потребу у соціальному контакті і підтримці в осіб, схильних до уникання в складних життєвих ситуаціях, важливо звертати увагу на формування в них соціальних, перцептивних, інтерактивних та комунікативних навичок, нарощення позитивного соціального досвіду, розвитку емоційного інтелекту, вміння керувати власним емоційним станом та вольової саморегуляції при виконанні простих завдань, що приносять задоволення у вигляді швидкого результату. Це дозволить знизити рівень емоційного напруження, збільшити ресурсність та психічну стійкість особистості, досягати кращих результатів під час виконання повсякденної діяльності, сприятиме формуванню стійкої та позитивної Я-концепції та впевненості у власних силах. Це дозволить в майбутньому суттєво розширити репертуар копінг-стратегій за рахунок активного використання більш продуктивних, функціональних та ефективних стратегій.

\section{ЛIТЕРАТУРА}

1. Berg C.A., Meegan S.P., Deviney P.P. A social-contextual model of coping with everyday problems across the lifespan. International Journal of Behavioral Development,1998, № 22(2): 231-237.

2. Koplik E.K. et al. The Relationship of Mother-Child Coping Styles and Mother's Presence of Children's Response to Dental Stress. The Journal of Psychology, 1992, № 126(1): 79-92.

3. Vitaliano P.P. et al. Coping Profiles Associated with Psychiatric, Physical Health, Work and Family Problems. Health Psychology, 1990, № 9(3): 348-376.

4. Быкова Д.В. Прокрастинация как проявление эмоционально-ориентированного и ориентированного на избегание копинга. Психология стресса и совладающего поведения. Материалы II Международной научно-практической конференции, Кострома, 2010, Т.2: 194 - 196.

5. Frydenberg E., Lewis R. Teaching Coping to adolescents: when and to whom? American Educational Research Journal, Fall 2000, T.37, № 3: 727-745.

6. Hofmann S.G., Hay A.C. Rethinking Avoidance: Toward a Balanced Approach to Avoidance in Treating Anxiety Disorders. URL: https://www.ncbi.nlm.nih.gov/pmc/articles/PMC5879019/

7. Carver C., Connor-Smith J. Personality and coping. Annual Review of Psychology. 2010, 61: 679-704. 
8. Hayes S.C., Strosahl K.D., Wilson K.G. Acceptance and commitment therapy. New York: The Guilford Press, 2012.

9. Aspinwall L.G., Taylor S.E. A stitch in time: self-regulation and proactive coping. Psychological Bulletin, 1997, 121: 417-36.

10. McKay M., Fanning P., Zurita P. Mind and Emotions: A Universal Treatment for Emotional Disorder. New Harbinger Publications, 2011: 190.

11. Herman-Stabl M.A., Stemmler M., Petersen A.C. Approach and avoidant coping: Implications for adolescent mental health. Journal of Youth and Adolescence, 1995, December (vol. 24, no.6): 649-665.

12. Seiffge-Krenke I. Social skill and coping style as risk and protective factors // In I. Seiffge-Krenke, I. (Ed.), Adolescents' health: a developmental perspective (pp. 1250150). Mahwah, NJ: Lawrence Erlbaum Associates, 1998.

13. Kliewer, W., \& Lewis, H. (1995). Family influences on coping processes in children and adolescents with sickle cell disease. Journal of Pediatric Psychology, 20(4): 511-525.

14. Causey David L., Dubow Eric E. Negotiating the Transition to Junior High School. Prevention in Human Services, 1994, 4 January (vol.10, no.2): 59-81.

15. Servatius R.G. Avoidance: From Basic Science to Psychopathology. URL: https://www.frontiersin.org/articles/10.3389/fnbeh.2016.00015/full

16. Losoya S., Eisenberg N., Fabes R.A. Developmental Issues in the Study of Coping. International Journal of Behavioral Development, 1998, June (vol.22, no.2): 287-313.

17. Kliewer, W., Sandler, I.N. (1993). Social competence and coping among children of divorce. American Journal of Orthopsychiatry, 1993, 63(3): 432-440.

18. Roth S., Cohen L.J. Approach, avoidance, and coping with stress. American Psychologist. 1986, 41: 813-819.

19. Frydenberg E. Beyond Coping. Meeting goals, visions and challenges, Oxford University Press, $2002,272$. 